\title{
Regulation of the oxidative stress response by the $h p r$ gene in Bacillus subtilis
}

\author{
Barbara C. A. Dowds ${ }^{1 *}$ and James A. Hoch ${ }^{2}$ \\ ${ }^{1}$ Department of Biology, St Patrick's College, Maynooth, Co. Kildare, Ireland \\ ${ }^{2}$ Division of Cellular Biology, Research Institute of Scripps Clinic, 10666 North Torrey Pines Road, La Jolla, \\ CA 92037, USA
}

(Received 3 September 1990; revised 17 January 1991; accepted 13 February 1991)

\begin{abstract}
Bacillus subtilis mutants with null mutations in the $\operatorname{spo} 0 A$ gene are resistant to oxidative stress during the exponential phase of growth. This resistance phenotype can be suppressed by mutations in the $a b r B$ gene, or in the $h p r$ gene. Both of these gene products are negative regulatory proteins which are over-produced in a $\operatorname{spo} 0 \mathrm{~A}$ strain, and the over-production of the $h p r$ gene product results from over-production of the $a b r B$ gene product. The resuits suggested that the resistance to oxidative stress in a $5 p o 0 \mathrm{~A}$ strain is due to the lack of a protein directly controlled by the $h p r$ negative regulator. Other mutations in the $s p o 0 A$ gene conferring resistance to ethanol stress $(e t h)$ or suppressors of sporulation phenotypes (sof) had no effect on the sensitivity to oxidative stress of strains bearing them.
\end{abstract}

\section{Introduction}

Bacteria have evolved mechanisms for allowing them to cope with a variety of stresses including the presence of oxidants in their environment. Sub-lethal levels of stressinducing agents evoke a protective response which allows the cells to survive more extreme levels of the same agent (or, in some cases, different agents) (Lindquist, 1986). The protective response to a given type of stress involves the induction of several proteins. There is overlap in the proteins induced in response to a diverse range of stresses, while some remain unique to the inducing agent (Morgan et al., 1986; Van Bogelen et al., 1987).

In one example of this phenomenon, sub-lethal levels $(50 \mu \mathrm{M})$ of hydrogen peroxide can induce a protective response in the obligate aerobe Bacillus subtilis so that the cells survive otherwise lethal concentrations ( $10 \mathrm{mM})$ of this agent. Treatment with $50 \mu \mathrm{M}-\mathrm{H}_{2} \mathrm{O}_{2}$ induces the synthesis of at least eight proteins, some of which may be important in the protective response (Murphy et al., 1987). Paradoxically, strains with mutations in the spo0A gene were constitutively resistant to $10 \mathrm{mM}-\mathrm{H}_{2} \mathrm{O}_{2}$, and some of the proteins induced (by $50 \mu \mathrm{M}-\mathrm{H}_{2} \mathrm{O}_{2}$ ) in the wild-type strains were synthesized constitutively in a $\operatorname{spo0A}$ mutant in the absence of stress (Dowds et al., 1987). Surprisingly, wild-type $B$. subtilis cultures become resistant to the effects of $10 \mathrm{mM}-\mathrm{H}_{2} \mathrm{O}_{2}$ upon reaching stationary phase (Dowds et al., 1987). Mutations in the spo0 genes which disrupt the expression of early stationary-phase and sporulation genes did not prevent the stationary phase resistance phenomenon.

The $\operatorname{spo} 0 A$ gene product is thought to be required for the initial stage of sporulation in which the cells detect changes in their environment which induce sporulation. spoOA mutants have extremely pleiotropic phenotypes which may result from the Spo0A protein controlling sporulation as well as the expression of a number of genes expressed at stationary phase (Hoch, 1976). Many of the stationary-phase genes are regulated by the spo0A gene via the $a b r B$ gene (Trowsdale et al., 1979). spo0A mutants over-express the AbrB protein, which is a transcription regulator acting negatively on the expression of many genes (Perego et al., 1988; Strauch et al., 1989). The AbrB protein also acts in a positive manner to induce the synthesis of the Hpr protein, which negatively regulates protease production and at least one gene required for sporulation (Perego \& Hoch, 1988).

In this work we investigated the pathway whereby spo0 $A$ regulates the oxidative stress response and found that over-expression of the $h p r$ gene leads to resistance of $B$. subtilis to oxidative stress during the exponential phase. 
Table 1. B. subtilis strains

\begin{tabular}{|c|c|c|}
\hline Strain & Genotype & Reference or source \\
\hline W168 & Wild-type & Bacillus Genetic Stock Center, \\
\hline JH642 & trpC2 phe-1 & Ohio State University, \\
\hline JH646 & trpC2 phe-1 spo0A12 & Columbus, Ohio, USA \\
\hline JH703 & trpC2 phe-1 spo0A $\triangle 204$ & Ferrari et al. (1985) \\
\hline Eth7 & $\operatorname{trp} C 2 s s a-7$ & Bohin \& Lubochinsky (1982) \\
\hline Eth415 & $\operatorname{trpC2}$ ssa-15 & Bohin \& Lubochinsky (1982) \\
\hline Sof 105 & $\operatorname{trpC} 2 \Delta$ spoOF sof-105 & Hoch et al. (1985) \\
\hline JH12588 & $\operatorname{trp} C 2$ phe-1 spo0A12 abrB $\triangle C A T$ & CM Pereon \& I A Hoch (unnublished) \\
\hline JH12607 & $\operatorname{trpC2}$ phe-1 abrB $\triangle C A T$ & YM. Perego \& J. A. Hoch (unpublished) \\
\hline $\mathrm{Hpr} 2$ & trpC2 hpr-2 & Perego \& Hoch (1988) \\
\hline JH12769 & trpC2 phe-1 spo0AI2 hpr $\triangle C A T$ & This study \\
\hline JH12611 & trpC2 phe-1 abrB $\triangle C A T$ amyE : :[abrB'-lacZ pC194CAT] & M. Perego \& J. A. Hoch (unpublished) \\
\hline JH12527 & $\operatorname{trpC2}:: p J M 2488\left[\mathrm{hpr}^{\prime}-{ }^{\prime} l a c Z\right]$ & Perego \& Hoch (1988) \\
\hline JH12464 & trpC2 phe-1 amyE::[aprE'-'lacZ pC194CAT] & Ferrari et al. (1988) \\
\hline
\end{tabular}

\section{Methods}

Strains. The Bacillus subtilis strains used in this study are listed in Table 1.

Growth conditions. B. subtilis was grown for all experiments in minimal medium as described by Murphy et al. (1987). Chloramphenicol $\left(5 \mu \mathrm{g} \mathrm{ml}^{-1}\right)$ was added where appropriate.

Induction of protection against oxidative stress. The method of Murphy et al. (1987) was used but was varied in the following details. Cultures were grown to an $\mathrm{OD}_{550}$ of 0.1 and treated with $\mathrm{H}_{2} \mathrm{O}_{2}$ at a final concentration of $100 \mu \mathrm{M}$ (inducing concentrations) for $15 \mathrm{~min}$ or $10 \mathrm{mM}$ (killing concentration) for $10 \mathrm{~min}$.

Induction of lac Z fusions with $\mathrm{H}_{2} \mathrm{O}_{2}$. B. subtilis strains containing lacZ fusions were grown to an $\mathrm{OD}_{550}$ of $0 \cdot 1$. Fractions of $1 \mathrm{ml}$ were removed into prewarmed $10 \mathrm{ml}$ culture tubes. Half of the tubes contained $\mathrm{H}_{2} \mathrm{O}_{2}$ at a final concentration of $100 \mu \mathrm{M}$ and half were untreated. The tubes were vigorously shaken at $37^{\circ} \mathrm{C}$ for various lengths of time $(15 \mathrm{~min}$ and $40 \mathrm{~min}$ in the case of the $a b r B$-lac $Z$ fusion and $10 \mathrm{~min}, 25 \mathrm{~min}$ and $45 \mathrm{~min}$ in the case of the hpr-lac $Z$ fusion and the apr-lac $Z$ fusion). The entire contents of each tube were then spun in an Eppendorf centrifuge for $5 \mathrm{~min}$ at $4{ }^{\circ} \mathrm{C}$, the supernatants were discarded and the pellets were frozen at $-70^{\circ} \mathrm{C}$. The thawed pellets were each resuspended in $1 \mathrm{ml} \mathrm{Z}$ buffer (Ferrari et al., 1986). An appropriate volume of the suspension was then lysed and assayed for $\beta$-galactosidase (Ferrari et al., 1986) so that the $A_{420}$ (of the $o$-nitrophenol reaction product) fell between 0.15 and $0 \cdot 6$.

\section{Results}

spo0A mutants and oxidative stress

We have previously shown the effects of $1 \mathrm{~h}$ treatments with $\mathrm{H}_{2} \mathrm{O}_{2}$ on the subsequent survival of wild-type and spoOA strains of B. subtilis (Dowds et al., 1987). We found considerable day-to-day variation in the effects of $\mathrm{H}_{2} \mathrm{O}_{2}$ and concluded that some or all of this variability could be attributed to the growth phase of the cells. In addition we found that a $10 \mathrm{~min} \mathrm{H}_{2} \mathrm{O}_{2}$ treatment was sufficient to give the maximum. However, even with a short exposure
Table 2. Percentage survival of $\mathrm{JH} 642\left(\mathrm{spoOA} \mathrm{A}^{+}\right)$after $\mathrm{H}_{2} \mathrm{O}_{2}$ treatment

The numbers in this and subsequent tables are the percentage survival of the treated cultures compared to the same culture untreated.

\begin{tabular}{llcr}
\hline \hline & \multicolumn{3}{c}{$\mathrm{H}_{2} \mathrm{O}_{2}$ treatment } \\
\cline { 2 - 4 } Expt & $10 \mathrm{mM}$ & $\begin{array}{c}100 \mu \mathrm{M}, \\
\text { then } 10 \mathrm{mM}\end{array}$ & $100 \mu \mathrm{M}$ \\
\hline 1 & 0.1 & $6 \cdot 7$ & 97 \\
2 & 0.23 & 48 & 100 \\
3 & 0.17 & $8 \cdot 7$ & 87 \\
4 & 0.003 & 9.0 & 73 \\
5 & 0.03 & 1.2 & 90 \\
\hline
\end{tabular}

time and treatment of the cells at exactly the same culture density, some day-to-day variation was still observed (e.g. Tables 2 and 3).

Table 2 shows the effect of induction by $100 \mu \mathrm{M}-\mathrm{H}_{2} \mathrm{O}_{2}$ on the subsequent challenge by $10 \mathrm{~mm}-\mathrm{H}_{2} \mathrm{O}_{2}$ in a sporulation-proficient strain. Typically about $0 \cdot 1 \%$ of the uninduced cells of strain JH642 survived a challenge with $10 \mathrm{mM}-\mathrm{H}_{2} \mathrm{O}_{2}$. Preinduction with $100 \mu \mathrm{M}-\mathrm{H}_{2} \mathrm{O}_{2}$ resulted in an increase in survival of 40 to several hundred fold. Similar experiments with the isogenic spo0A mutant strain JH646 showed that the mutant strain was constitutively five- to 6000 -fold more resistant to challenge with $10 \mathrm{mM}-\mathrm{H}_{2} \mathrm{O}_{2}$ (Table 3 ). Preinduction of the $\operatorname{spo} 0 A$ mutant strain still resulted in a $2-50$-fold increase in survival over the uninduced culture and the strain was resistant to $\mathrm{H}_{2} \mathrm{O}_{2}$ in the stationary phase. The classical wild-type strain, W168, gave the same results as JH642 (data not shown).

Treatment of other strains carrying mutations in the spo0 $A$ locus (Table 4 ) revealed that their oxidative stress 
Table 3. Percentage survival of JH646 (spo0 A12) after $\mathrm{H}_{2} \mathrm{O}_{2}$ treatment

\begin{tabular}{cccr}
\hline \hline & \multicolumn{3}{c}{$\mathrm{H}_{2} \mathrm{O}_{2}$ treatment } \\
\cline { 2 - 4 } Expt & $10 \mathrm{mM}$ & $\begin{array}{c}100 \mu \mathrm{M}, \\
\text { then } 10 \mathrm{mM}\end{array}$ & $100 \mu \mathrm{M}$ \\
\hline 1 & $5 \cdot 8$ & 19 & 78 \\
2 & 19 & 33 & 113 \\
3 & $1 \cdot 2$ & 67 & 100 \\
4 & $1 \cdot 1$ & 24 & 93 \\
5 & 10 & 24 & 114 \\
\hline \hline
\end{tabular}

phenotype correlated with the functionality of the $\operatorname{spo} 0 \mathrm{~A}$

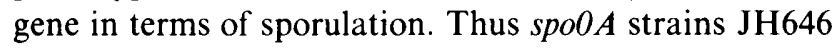
(nonsense mutation, spo0A12) (Kudoh et al., 1985) and JH703 (deletion mutation) (Ferrari et al., 1985) are both unable to sporulate because of loss of the Spo0A protein and both are resistant to oxidative stress. On the other hand two mutations in the $\operatorname{spo} 0 A$ locus which have a $\mathrm{Spo}^{+}$phenotype cause a wild-type inducible oxidative stress phenotype. These include the eth-7 and eth-415 mutations, which make strains resistant to inhibition of sporulation by ethanol (Bohin \& Lubochinsky, 1982). The sof-105 bearing strain, which has a mutation in the spo0 $A$ gene resulting in sporulation becoming independent of the $\operatorname{spoOB}$, spoOE and spoOF genes (Hoch et al., 1985) has a phenotype intermediate between those of the wild-type and the $\operatorname{spo} 0 \mathrm{~A}$ null mutants.

\section{Resistance to oxidative stress of spoOA abr B mutants}

The Spo0A protein is a negative regulator of expression of the $a b r B$ gene (Perego et al., 1988). Null mutations in the $a b r B$ gene suppress most of the stationary-phase defects but not the sporulation defects of spoOA mutants. We found that an $a b r B$ mutation suppressed the exponential-phase resistant oxidative stress phenotype of a $\operatorname{spo} 0 A$ mutant (Table 5). The $\operatorname{spo0A} a b r B$ double

Table 4. Percentage survival of spoOA mutants after $\mathrm{H}_{2} \mathrm{O}_{2}$ treatment

\begin{tabular}{llcr}
\hline & \multicolumn{3}{c}{$\mathrm{H}_{2} \mathrm{O}_{2}$ treatment } \\
\cline { 2 - 4 } Strain & $10 \mathrm{mM}$ & $\begin{array}{c}100 \mu \mathrm{M}, \\
\text { then } 10 \mathrm{mM}\end{array}$ & $100 \mu \mathrm{M}$ \\
\hline JH703 & 9 & 20 & 95 \\
Eth7 & 0.009 & 1.7 & 89 \\
Eth415 & 0.11 & 3.8 & 54 \\
Sof105 & 0.35 & 24 & 100 \\
\hline \hline
\end{tabular}

Table 5. Percentage survival of $B$. subtilis strains after treatment with $\mathrm{H}_{2} \mathrm{O}_{2}(10 \mathrm{mM}$ or $100 \mu \mathrm{M})$

\begin{tabular}{|c|c|c|c|c|}
\hline \multirow[b]{2}{*}{ Strain } & \multirow[b]{2}{*}{$\begin{array}{l}\text { Relevant } \\
\text { genotype }\end{array}$} & \multicolumn{2}{|c|}{ Exponential phase } & \multirow{2}{*}{$\begin{array}{l}\text { Stationary phase } \\
\qquad 10 \mathrm{mM}\end{array}$} \\
\hline & & $10 \mathrm{~mm}$ & $\begin{array}{c}100 \mu \mathrm{M}, \\
\text { then } 10 \mathrm{mM}\end{array}$ & \\
\hline JH12588 & $s p o 0 A a b r B$ & $\begin{array}{l}0.017 \\
0.018 \\
0.015 \\
0.010\end{array}$ & $\begin{array}{l}0.42 \\
0.75\end{array}$ & 44 \\
\hline JH12607 & $a b r B$ & 0.019 & $2 \cdot 8$ & ND \\
\hline Hpr2 & hpr & 0.09 & 2 & 80 \\
\hline JH12769 & spo0A hpr & $\begin{array}{l}0.006 \\
0.001 \\
0.0008\end{array}$ & $\begin{array}{l}41 \\
0.89 \\
0.017\end{array}$ & 100 \\
\hline
\end{tabular}

ND, Not determined.

mutant remained inducible by $100 \mu \mathrm{M}-\mathrm{H}_{2} \mathrm{O}_{2}$ and showed the typical stationary-phase resistance. A strain bearing the $a b r B$ mutation in the absence of the $\operatorname{spo} 0 A$ mutation was indistinguishable from the wild-type in stress phenotype (Table 5).

\section{Effect of the hpr mutation on resistance to oxidative stress}

The $a b r B$ mutation may suppress $\operatorname{spo} 0 A$ mutations directly or indirectly via its control of expression of other genes. $s p o 0 A$ mutations lead to over-expression of the $a b r B$ gene, which is in turn responsible for overproduction of the hpr gene product (Perego \& Hoch, 1988; Strauch et al., 1989). It was of interest to determine if the stress phenotype of $\operatorname{spo} 0 \mathrm{~A}$ mutants was due to a direct effect of $a b r B$ or to one of the gene products controlled by the $a b r B$ gene since an $a b r B$ mutation suppressed the spo0A phenotype. In order to test whether the $h p r$ gene was involved in the stress resistance phenomenon, we constructed a $s p o 0 \mathrm{~A}$ hr strain by transforming a $\operatorname{spo} 0 \mathrm{~A}$ mutant with plasmid pJM2479 (Perego \& Hoch, 1988), which contains an internal fragment of the $h p r$ gene. Integration of this plasmid by Campbell recombination inactivates the hpr gene. When this mutant was tested in our usual protocol, it was found that the $\mathrm{H}_{2} \mathrm{O}_{2}$ resistance of the strain conferred by the $\operatorname{spoOA}$ mutation was suppressed by the hpr mutation (Table 5). Thus, the spoO $A$ effect is an indirect consequence of the $\operatorname{spo} 0 A$ mutation in that the hpr gene is over-expressed in the spoOA strains and it is this over-expression that presumably results in constitutive expression of the stress resistance.

We found that $h p r$ deletion mutants and $a b r B$ mutants showed a wild-type inducible stress response (Table 5). Thus, while $h p r$ over-expression leads to protection 
against oxidative stress, it is not required for the protection induced by pre-treatment with $100 \mu \mathrm{M}-\mathrm{H}_{2} \mathrm{O}_{2}$. Therefore protection can be induced in two completely independent ways.

\section{The hpr gene is not required for the resistance of stationary-phase cells to oxidative stress}

Wild-type $B$. subtilis has an inducible stress response during the exponential phase but a constitutive response (i.e. resistance to $10 \mathrm{~mm}-\mathrm{H}_{2} \mathrm{O}_{2}$ ) at stationary phase (Dowds et al., 1987). We hypothesized that the constitutive stationary-phase resistance might be caused by the increase in expression of the $h p r$ gene at stationary phase (Perego \& Hoch, 1988). However, we found (Table 5) that this is not the case and that $h p r$ deletion mutants are as resistant as wild-type cells to $\mathrm{H}_{2} \mathrm{O}_{2}$ at stationary phase.

Effect of oxidative stress on the expression of abrB-and hpr-controlled genes

We considered the possibility that while the $h p r$ gene product was not necessary for the induction of protection with $100 \mu \mathrm{si}-\mathrm{H}_{2} \mathrm{O}_{2}$, it might nevertheless constitute part of one route whereby $\mathrm{H}_{2} \mathrm{O}_{2}$ could induce protection. Thus we asked whether the $h p r$ gene product was induced by $100 \mu \mathrm{M}-\mathrm{H}_{2} \mathrm{O}_{2}$. Using fusions of the regulatory region of $h p r$ to a promoterless lacZ gene (strain JH12527; Perego \& Hoch, 1988) we found that $\beta$-galactosidase was not induced by the addition of $100 \mu \mathrm{M}-\mathrm{H}_{2} \mathrm{O}_{2}$, to the medium. The specific activity in the absence $(-)$ and presence $(+)$ of $\mathrm{H}_{2} \mathrm{O}_{2}$, was $13(-)$ and $13(+) \mathrm{U} \mathrm{mg}^{-1}$ $\left(10 \mathrm{~min}\right.$ treatment), $33(-)$ and $30(+) \mathrm{U} \mathrm{mg}^{-1}(25 \mathrm{~min}$ treatment) and $37(-)$ and $43(+) \mathrm{U} \mathrm{mg}^{-1}(45 \mathrm{~min}$ treatment). Similarly, we found that $\beta$-galactosidase was not induced by $100 \mu \mathrm{M}-\mathrm{H}_{2} \mathrm{O}_{2}$ in an $a b r B-l a c Z$ transcriptional fusion (strain JH12611; Perego et al., 1988). Here the specific activity was $1800(-)$ and $1700(+) \mathrm{U} \mathrm{mg}^{-1}$ (15 min treatment) and $1400(-)$ and $1200(+) \mathrm{U} \mathrm{mg}^{-1}$ (40 min treatment) Thus, $\mathrm{H}_{2} \mathrm{O}_{2}$ is unable to induce in exponentiai growth either the $a b r B$ gene or the $h p r$ gene.

Since the $h p r$ gene product is known to directly control the synthesis of subtilisin in B. subtilis (Ferrari et al., 1988) we asked whether the subtilisin gene was controlled by conditions of oxidative stress. Thus, a strain carrying the promoter region of the alkaline protease gene, aprE, connected to the lac $Z$ gene $(\mathrm{JH} 12464)$ was treated with $100 \mu \mathrm{M}-\mathrm{H}_{2} \mathrm{O}_{2}$ and the production of $\beta$ galactosidase determined. The specific activity was 26 $(-)$ and $28(+) \mathrm{U} \mathrm{mg}^{-1}(10 \mathrm{~min}$ treatment), $31(-)$ and $25(+) \mathrm{U} \mathrm{mg}^{-1}(25 \mathrm{~min}$ treatment$)$ and $19(-)$ and 18 (+) $\mathrm{U} \mathrm{mg}^{-1}$ (45 min treatment). In this case, as above, no induction of $\beta$-galactosidase was found due to the oxidative stress conditions.

\section{Discussion}

There appear to be at least two different mechanisms by which $B$. subtilis cells respond to oxidative stress, an hprdependent and an $h p r$-independent mechanism. None of the mutations tested affect the inducible phenotype although the uninduced level of resistance to $10 \mathrm{mM}$ $\mathrm{H}_{2} \mathrm{O}_{2}$ may be different depending upon the mutant strain. Furthermore all of the mutant strains are resistant to $10 \mathrm{mM}-\mathrm{H}_{2} \mathrm{O}_{2}$ in the stationary phase of growth. Thus inducibility and resistance in stationary phase are unimpaired in all of these mutants and it is impossible to determine from these data whether induction and stationary-phase resistance are brought about by the same or different mechanisms.

The phenomenon addressed by the results presented here is the observed constitutive resistance of $\operatorname{spo} 0 \mathrm{~A}$ strains to high levels of $\mathrm{H}_{2} \mathrm{O}_{2}$ (Dowds et al., 1987). It was found in the previous work that other strains with mutations in $s p o 0$ genes $(s p o O B, s p o O E, s p o O F, s p o O H$ and $s p o O J$ ) were identical to the wild-type parental strain in their response to oxidative stress. However, in a $\operatorname{spo} 0 \mathrm{~A}$ strain, mid-exponential-phase cells are 100 -fold more resistant to $10 \mathrm{mM}-\mathrm{H}_{2} \mathrm{O}_{2}$ than the wild-type or the other spo0 strains. The focus of the experiments described here was to determine if the oxidative stress phenomenon is a direct consequence of $5 p o 0 \mathrm{~A}$ activity or if it results from the other regulatory proteins controlled by $s p o 0 A$.

In a $\operatorname{spo} 0 A$ mutant, negative regulation of the $a b r B$ locus is lost, with the consequence that the $a b r B$ gene product is overproduced (Perego et al., 1988; Strauch et al., 1989). Overproduction of the AbrB protein is responsible for overproduction of the $h p r$ gene product, which is itself a negative regulatory protein controlling the transcription of several genes (Perego \& Hoch, 1988). The introduction of an $a b r B$ mutation into a $s p o 0 A$ strain results in the return of $h p r$ expression to normal levels. Thus, one consequence of mutation in the $\operatorname{spo} 0 \mathrm{~A}$ gene is to overproduce the $\mathrm{Hpr}$ negative regulator and therefore repress those genes controlled by the $h p r$ gene product. It was found in this study that a mutation in the $h p r$ gene could suppress the oxidative resistance phenotype of the spo0A strain, suggesting that $\mathrm{Hpr}$ can behave as both a positive and a negative regulator and that $\mathrm{Hpr}$ is a positive regulator for a resistance determinant. Alternatively $\mathrm{Hpr}$ may behave as a negative regulator only but might negatively regulate a repressor of a proposed resistance gene.

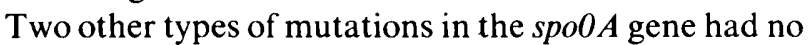
effect on the $\mathrm{H}_{2} \mathrm{O}_{2}$ sensitivity phenotype of strains 
bearing them. Resistance to ethanol stress can be caused by eth mutations in the $s p o 0 A$ gene (Bohin \& Lubochinsky, 1982). Such mutations did not confer resistance to oxidative stress. Thus, the role of the Spo0A protein in ethanol stress must be different from its role in oxidative stress sensitivity. Similarly, the sof mutations are alterations in the $5 p 00 \mathrm{~A}$ gene that compensate for the lack of all of the other $\mathrm{spo} 0$ genes except for $\mathrm{spoOH}$ (Hoch et al., 1985). These proteins must have some unique regulatory properties but the one allele tested, sof-105, did not change the $\mathrm{H}_{2} \mathrm{O}_{2}$ sensitivity phenotype of the strain.

Regulation of the bacterial oxidative stress response has been most studied in enteric bacteria. The oxyR locus regulates expression of genes which protect Escherichia coli and Salmonella typhimurium against oxidative stress (Christman et al., 1985; Goerlich et al., 1989; Storz et al., 1990). We here discuss another regulatory gene, $h p r$, which controls the oxidative stress response in $B$. subtilis. However the $h p r$ gene seems to play a different role from the $\operatorname{oxy} R$ gene. The $h p r$ gene regulates the resistance of $B$. subtilis to high concentrations of $\mathrm{H}_{2} \mathrm{O}_{2}$ but unlike oxyR it is not involved in the induction of protection by low concentrations of $\mathrm{H}_{2} \mathrm{O}_{2}$.

This research was supported in part by grants GM19416 and GM39442 from the National Institute of General Medical Services, USPHS. This is publication number 6131-MEM from the Department of Molecular and Experimental Medicine. We thank Dr M. Perego for providing many of the strains used.

\section{References}

BoHIN, J.-P. \& LUBOCHINSKY, B. (1982). Alcohol-resistant sporulation mutants of Bacillus subtilis. Journal of Bacteriology 150, 944-955.

Christman, M. F., Morgan, R. W., Jacobson, F. S. \& Ames, B. N. (1985). Positive control of a regulon for defenses against oxidative stress and some heat-shock proteins in Salmonella typhimurium. Cell 41, 753-762.

Dowds, B. C. A., Murphy, P., McConnell, D. J. \& Devine, K. M. (1987). Relationship among oxidative stress, growth cycle, and sporulation in Bacillus subtilis. Journal of Bacteriology 169, 57715775 .

Ferrari, F. A., Trach, K., LeCoQ, D., Spence, J., Ferrari, E. \& Hoch, J. A. (1985). Characterization of the spoOA locus and its deduced product. Proceedings of the National Academy of Sciences of the United States of America 82, 2647-2651.
Ferrari, E., Howard, S. M. H. \& Hoch, J. A. (1986). Effect of stage 0 sporulation mutations on subtilisin expression. Journal of Bacteriology 166, 173-179.

Ferrari, E., Henner, D. J., Perego, M. \& Hoch, J. A. (1988). Transcription of Bacillus subtilis subtilisin and expression of subtilisin in sporulation mutants. Journal of Bacteriology 170, 289295.

Goerlich, O., Quillardet, P. \& HofNung, M. (1989). Induction of the SOS response by hydrogen peroxide in various Escherichia coli mutants with altered protection against oxidative DNA damage. Journal of Bacteriology 171, 6141-6147.

Носн, J. A. (1976). Genetics of bacterial sporulation. Advances in Genetics 18, 69-98.

Hoch, J. A., Trach, K., Kawamura, F. \& Saito, H. (1985), Identification of the transcriptional suppressor sof-1 as an alteration in the spoOA protein. Journal of Bacteriology 161, 552-555.

KUDOH, J., IKEUCHI, T. \& KURAHASHI, K. (1985). Nucleotide sequences of the sporulation gene spoOA and its mutant genes of Bacillus subtilis. Proceedings of the National Academy of Sciences of the United States of America 82, 2665-2668.

LINDQUIST, S. (1986). The heat-shock response. Annual Review of Biochemistry 55, 1151-1191.

Morgan, R. W., Christman, M. F., Jacobson, F. S., Storz, G. \& AMES, B. N. (1986). Hydrogen peroxide-inducible proteins in Salmonella typhimurium overlap with heat shock and other stress proteins. Proceedings of the National Academy of Sciences of the United States of America 83, 8059-8063.

Murphy, P., Dowds, B. C. A., McConnell, D. J. \& Devine, K. M (1987). Oxidative stress and growth temperature in Bacillus subtilis. Journal of Bacteriology 169, 5766-5770.

Perego, M. \& HoCH, J. A. (1988). Sequence analysis and regulation of the $h p r$ locus, a regulatory gene for protease production and sporulation in Bacillus subtilis. Journal of Bacteriology 170, 25602567.

Perego, M., Spiegelman, G. B. \& Hoch, J. A. (1988). Structure of the gene for the transition state regulator, $a b r B$ : regulator synthesis is controlled by the spoOA sporulation gene in Bacillus subtilis. Molecular Microbiology 2, 689-699.

StoRz, G., Tartaglia, L. A. \& Ames, B. N. (1990). Transcriptional regulator of oxidative stress-inducible genes: direct activation by oxidation. Science 248, 189-194.

Strauch, M. A., Spiegelman, G. B., Perego, M., Johnson, W. C., BurbulYs, D. \& HoCH, J. A. (1989). The transition state regulator $a b r B$ of Bacillus subtilis is a DNA binding protein. EMBO Journal 8 , 1615-1621.

Trowsdale, J., Chen, S. M. H. \& Hoch, J. A. (1979). Genetic analysis of a class of polymyxin resistant partial revertants of stage 0 sporulation mutants of Bacillus subtilis: map of the chromosome region near the origin of replication. Molecular and General Genetics 173, 61-70.

Van Bogelen, R. A., Kelley, P. M. \& Neidhardt, F. C. (1987). Differential induction of heat shock, SOS, and oxidation stress regulons and accumulation of nucleotides in Escherichia coli. Journal of Bacteriology 169, 26-32. 